\title{
HOLOCENE SEA LEVEL CHANGES IN THE TIERRA DEL FUEGo REgION
}

N.A.Mörner'

\section{ABSTRACT}

Avallable sea level data from the Tierra del Fuego region cannot be combined into a meaningful sea level graph as recently proposed (PORTER et al., 1984 and RABASSA et al., 1986) because these records are dominated by sites of local seismotectonic uplift; i.e., the exceptions, not the rule. The general sea level tendency (i.e., the rule), gives a sea level rise from 9,000 up to about 4,000 BP when the peak-level was reached. This Holocene maximum level was, however, at or just above the present sea level; ranging from zero via 0.5-1.0 $\mathrm{m}$ up to 1-2 $\mathrm{m}$ above the present sea level. A preliminary regional eustatic curve is proposed. Presently available sea level data do not record any Holocene glacial isostatic effects.

\section{INTRODUCTION}

PORTER et al. (1984) and RABASSA et al. (1986) have presented sea level curves for the Tierra del Fuego region. We made independent investigations during the Swedish Expeditions to Argentina in 1987 and 1989 that give quite a different sea level picture (reported on in a few brief notes; MÖRNER, 1987, 1989a, 1989b). All the presently available sea level data (Fig. 1) are here given a critical examination.

\section{DIFFERENCES IN APPROACHES}

PORTER et al. (1984) and RABASSA et al. (1986) both seem to look for elevated and by

\footnotetext{
'Paleogeophysics \& Geodynamics, Geological Institute, S-10691 Stockholm, Sweden.
} 


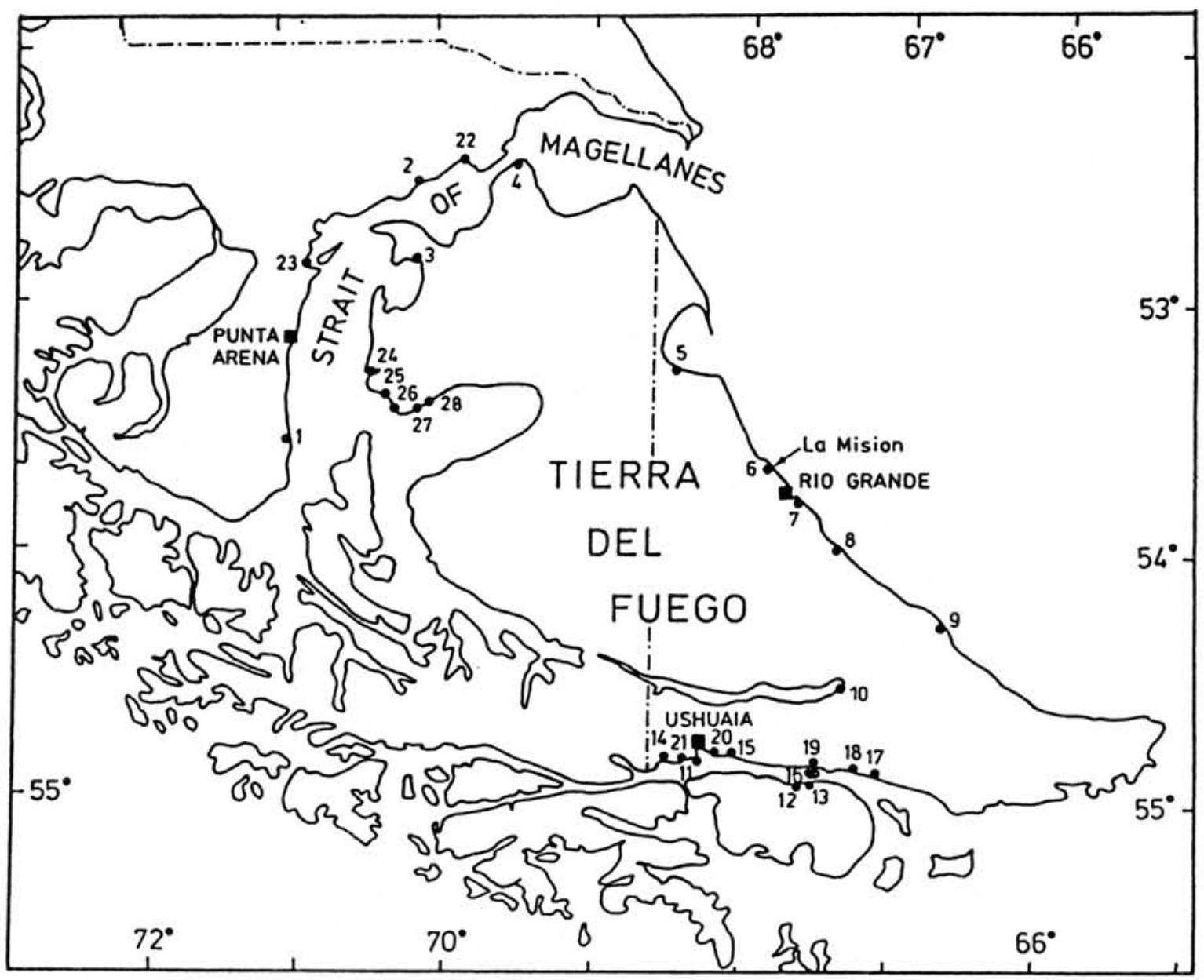

Figure 1 - The Tierra del Fuego region with sea level sites discussed in the text: (1) Puerto del Hambre, (2) Bahia San Gregorio, (3) Bahia Gente Grande, (4) Bahia Azul, (5) San Sebastian, (6) Misión Salesiana and La Misión, (7) Punta Maria, (8) Cape Viamonte, (9) San Pablo (Pirinaica), (10) Lago Fagnano (1949 seismotectonics), (11) Punta Pinguinos and Ushuaia Peninsula, (12) Peninsula Gusano, (13) Punta Piedra Buena, (14) Lapataia and Lago Roca, (15) Estancia Tunel, (16) Gable Island, (17) Rio Cambaceres, (18) Harberton, (19) Gable Island and terminal moraine, (20) Rio Olivia, (21) Ensenda (22) Bahia Santiago, (23) Chorrillo la Lota, (24) Porvenir, (25) Lago Barroza, (26) Estancia Futura, (27 and 28) Coleta Rosario.

that identifiable - shore level deposits above the present high tide level. This implies a selection.

We prefer at first to analyze the general characteristics of the region or locality including the determination of negative evidence - "to what level did sea level not reach" - and to try to establish what is the rule and what is the exception. Obviously, occasional high sea level data have a strong statistical possibility to represent the exceptions rather than the rule.

The Tierra del Fuego region is a tectonically-geodynamically highly active area, why there are all reasons to expect that the sea level data should record a strong component of local tectonic 
differentiation. This is not the case in the approaches of PORTER et al. (1984) and RABASSA et al. (1986). In our analysis, however, we believe that this sets the characteristics of the Holocene sea level changes in this region. Furthermore, we see no effects of any glacial isostatic uplift during the Holocene (MÖRNER, 1987) as claimed to be documented in the analyses of PORTER et al. (1984) and RABASSA et al. (1986).

PORTER et al. (1984) combined data from all around Tierra del Fuego into a sea level graph. We think this is a serious mistake, and that each locality or subarea must be treated individually as to identify the tectonic differentiation. RABASSA et al. (1987) presented data from the Beagle Channel region. Even here, however, the differential tectonics seem to be a major problem. We will here analyze this particular question.

\section{THE STRAIT OF MAGELLANES}

At Bahia Azul (4 in Fig. 1), we have good stratigraphical-morphological evidence that the the Holocene sea level never reached above $1.5 \mathrm{~m}$ above the high tide level, HTL (MÖRNER, 1987). This level marks the top of a shingle beach rich in shells. Marine shells at higher levels within eolian sand (the dunes) occur, but do only represent the redeposition of shells by the wind (a process that we could observe in progress during a quite heavy storm).

PORTER et al. (1984) present data from 3 localites. In the bog of Puerto del Hambre (1 in Fig. 1), there is a transgression contact at $2.05 \mathrm{~m}$ above HTL dated at about $8,000 \mathrm{BP}$ and a regression contact at $3.50 \mathrm{~m}$ above HTL dated at about 4,000 BP. At Bahia San Gregorio (2 in Fig. 1), there is a beach gravel with shells at $3.0 \mathrm{~m}$ above $\mathrm{HTL}$ that is dated at about 3,850 BP and represents the Holocene sea level culmination, the Marine Limit, in this area. At Bahia Gente Grande (3 in Fig. 1), there are dipping shore deposits that are dated at 5,850 BP at their highest level at $3.4 \mathrm{~m}$ above $\mathrm{HTL}$, at 5,625 BP at the $3.0 \mathrm{~m}$ level and at 4,600 BP at $2.0 \mathrm{~m}$ level.

A total transgression amplitude of only $1.5 \mathrm{~m}$ between 8,000 and 4,000 BP (in Puerto del Hambre) is an unusually small amplitude in comparison with other international curves (e.g., MÖRNER, 1980, Fig. 16). The Holocene culmination elevation ( 3.5 and $3.0 \mathrm{~m}$ above $\mathrm{HTL}$ ) and age, 4,000 and $3,850 \mathrm{BP}$, in Puerto del Hambre and San Gregorio seem to agree well mutually. There is a 2,000 year difference to the culmination recorded in Gente Grande, and a $2 \mathrm{~m}$ differences to the highest Holocene level recorded at Bahia Azul, however. This does not concur with eustatic sea level changes, but indicates a strong influence of local tectonic differentiation.

During the 1989 expedition, we visited this area, levelled 29 coastal sections, cored the Puerto del Hambre bog and sampled several other coastal sections. This gave a quite new picture. In general, there is no high Holocene sea levels (a maximum of only $+0.2-0.3 \mathrm{~m}$ was recorded some $30-40 \mathrm{~km}$ 
south of Punta Arenas). A distinct shoreline, the marine limit, in the Punta Arenas area at about $+6-7 \mathrm{~m}$ was found to be of late glacial (not Holocene as previously assumed) age. In several places, it is covered by loess deposits. Furthermore, it is associated with a late glacial marine clay. This shoreline exhibits a tilt both to the north and to the east. Obviously, this tilt represents a glacial isostatic uplift component that operated in association with the ice recession but had finished in Holocene time.

In Bahia Santiago (22 in Fig. 1), there is a double beach system; a young trangressive sequence that culminates at $+1.2-1.0 \mathrm{~m}$, and an old system that ends at about $+5-6 \mathrm{~m}$.

At San Gregorio, there are no traces of a Holocene high stand; only a dune field inside the present day beach ridge, and an old (pre-Holocene) shore terrace at about $+5 \mathrm{~m}$. In Bahia San Gregorio (2 in Fig. 1), the Holocene maximum is at or shortly above the present shore. An overgrown shore deposits occur up to $0.6 \mathrm{~m}$ above the presently washed shore material. In the northern part of the bay, there is even a notch $1.5 \mathrm{~m}$ above the present HWM. No $+3 \mathrm{~m}$ beach, as reported by PORTER et al. (1984) was found, however.

In the Punta Arenas area, from Chorrilho la Leta (23 in Fig. 1) in the north to Puerto del Hambre (1 in Fig. 1) in the south, there are partly and old distinct shoreline (obviously the Marine Limit) that lies at about +6-7 m south of Punta Arenas and dips down to about $+3 \mathrm{~m}$ in the northern sector, and partly a general absence of higher Holocene shore deposits except for a formerly higher Holocene level at $+0.2-$ $0.3 \mathrm{~m}$ in the area $30-40 \mathrm{~km}$ south of Punta Arenas.

We re-cored the Puerto del Hambre peat bog of PORTER et al. (1984). The bog surface is $7 \mathrm{~m}$ above the HWM and is separated from the sea by a series of littoral ridges. The stratigraphy is sixparted:

(1) $340 \mathrm{~cm}$ of peat

(2) $14 \mathrm{~cm}$ of gyttja (representing a short ground water rise)

(3) $24 \mathrm{~cm}$ of peat with gyttja at its base

(4) $21 \mathrm{~cm}$ of grey clay (representing a major Holocene ground water rise)

(5) $23 \mathrm{~cm}$ of peat and black humus (land surface)

(6) $<5 \mathrm{~cm}$ of bluish clay (representing a late glacial marine phase)

The base of the middle peat is dated at about 3,500 BP, and the lower peat and humus at about 8,000 BP in the top and 15,800 BP in base (PORTER et al., 1984). Consequently, a long land period separated a late glacial marine episode and a Holocene ground water rise as an inland consequence of the main Holocene transgression, reaching the present level in mid-Holocene time.

The late glacial shore deposits and marine clay beds further north along the coast are often covered by a loess layer, indicating their late glacial age in agreement with the radiocarbon date of 15,800 from the base of the terrestrial bed in the bog at Puerto del Hambre (not Holocene, as previously assumed; Porter et al., 1984). The late glacial clay beds investigated include shells of marine molluscs. The 
clay and loess bed (like the stratal sequence at Puerto del Hambre) were sampled for paleomagnetism (and dating) in three separate localities (14, 27 and $35 \mathrm{~km}$ south of Punta Arenas).

At Porvenir on the other side of the Strait of Magellanes (24 in Fig. 1), we measured old shore terraces at 5.3-5.8 $\mathrm{m}$ above HWM and a Holocene level not exceeding the present level. Along the northern shore of Bahia Inutill, we measured four shore profiles (25-28 in Fig. 1). At Lago Barroza (25 in Fig. 1), there is an old shore at $5.8 \mathrm{~m}$ above HWM and a covering loess bed that goes down to the present shore where the Holocene shore has cut a little notch at $0.3 \mathrm{~m}$ above HWM (inland the present shore and HWM). This seems to mark a local Holocene maximum of $+0.3 \mathrm{~m}$. Shells occur, at least, up to $1.5 \mathrm{~m}$ above HWM. At Estancia Futura (26 in Fig. 1), there is a late glacial shore mark at $4.2 \mathrm{~m}$ above HWM and no sign of any Holocene littoral deposits above the present beach deposits. In the Coleta Rosario area (27-28 in Fig. 1), there is a loess covered beach deposit reaching $1.5 \mathrm{~m}$ above HWM. Obviously, this is of late glacial age. There are no sign of any Holocene maximum deposits above the present beach. Further eastwards (28 in Fig. 1), there is a distinct shore terrace (the maximum in the area) at about $5.0 \mathrm{~m}$ above HWM. This terrace dips seawards (down to $3.7 \mathrm{~m}$ above WM) where it is cut by the subsequent Holocene maximum shore erosion. A notch at $\mathbf{0 . 2} \mathrm{m}$ above HWM represents the maximum Holocene sea level position.

Taken together, the Bahia Inutil area exhibits a late glacial maximum shore level that dips gently to the east, and a Holocene maximum that peaked at the present level or, at the most, some $0.2-0.3$ m above it.

\section{THE RIO GRANDE AREA}

Along the eastern side of Tierra del Fuego, a maximum Holocene sea level can usually be followed at an elevation of $2-3 \mathrm{~m}$ above HTL AUER $(1959,1974)$ reported much higher Holocene and late glacial sea levels. Unfortunately, these levels do not hold for a critical field examination. The highest marine limit after the last glaciation is undoubtedly the above-mentioned Holocene level at about 2-3 $\mathrm{m}$ above HTL.

At San Sebastian (5 in Fig. 1), an elevated Holocene shore plain at about $2-3 \mathrm{~m}$ above HTL can be followed up to an old fossil shore cliff.

At Misión Salesiana north of Rio Grande (6 in Fig. 1), there is a distinct fossil cliff with a progradational coastal plain of successive beach ridges (or cheniers). This raised Holocene coastal plain reaches an altitude of about 2-3 m above the HTL Contrary to what Auer stated (AUER, e.g. 1959, 1974), sea level can never have been higher during the entire postglacial time of the region.

Inside the beach ridge system, there is a deep lagoonal area. Obviously, this represents a tidal flat environment. The present height is some $2-3 \mathrm{~m}$ above HTL A $2.7 \mathrm{~km}$ long profile across the coastal plain was levelled in 1989. 
This lagoonal area is the place of the famous drill site of "La Misión" (AUER, 1959, 1974; FRENGUELU, 1951, 1953; CAPPRANNINI, 1954; MARKGRAF, 1980 and MÖRNER, 1989a, 1989b) and "Turbera del Cabo Domingo" (VON POST, 1931, 1946).

AUER $(1959,1974)$ claimed that his sedimentary record gave evidence of several highamplitude sea level oscillations during the last 12,000 years. At the base of the marine deposits, there was a peaty layer (at $8.2 \mathrm{~m}$ depth) of an initial level phase. At a depth of $7.6 \mathrm{~m}$ there was a second peaty layer dated at about $7,850 \mathrm{BP}$.

In 1975, MARKGRAF (1980) made a new drilling at the same site. She established an initial lake phase at a depth of $8.7 \mathrm{~m}$, dated at about $9,000 \mathrm{BP}$, a subsequent marine stage of $8.2 \mathrm{~m}$, and finally a terrestrial stage with peat formation.

In 1987, we made a third drilling at the same site for paleomagnetic analyses (MÖRNER, 1989c). Our corer stopped at hard boulder clay at a depth of $11.5 \mathrm{~m}$ (once exposed for subaerial weathering). After a short initial lake phase (only $25 \mathrm{~cm}$ thick in our core), a long lagoonal - or rather tidal flat - sequence commenced (from 11.2 to $0.4 \mathrm{~m}$ depth), finally ending in a thin covering peat layer (0.4 $\mathrm{m}$ ) with the top of the underlying clay strongly weathered into a dry crust (i.e., an exposed land surface before the peat overgrowth). At a depth of about $2.12 \mathrm{~m}$, the lagoonal clay and silt change character which seems to represent the change from tidal flat conditions to lacustrine conditions. The identification of the marine deposits as tidal flat deposits, implies that they were built up approximately to mean high tide level.

In 1989, we cored three additional points so that a profile of four cores (with $25 \mathrm{~m}$ spacing) was established (Fig. 4). The elevation was levelled with a high precision instrument in a $2.7 \mathrm{~km}$ profile, crossing five beach ridge systems and a tidal flat plain up to the little lake and bog where the cores were taken.

Taken together, this means that an early Holocene lake at a level of $5.7 \mathrm{~m}$ below HTL at about $9,000 \mathrm{BP}$ was transgressed by the sea, turning it to a lagoonal tidal flat environment. The tidal flat surface was successively built up to an elevation of about $0.9 \mathrm{~m}$ above HTL This level seems to have been reached in late Holocene time or at about 4,000-2,000 BP. Thereafter, sea level successively fell to its present position as recorded in the progradational coastal plain.

For our sea level records, this provides two time/depth point; a transgression level of 5.7 $\mathrm{m}$ below HTL, and a regression level of $0.9 \mathrm{~m}$ above HTL A closer analysis is given below (Fig. 4).

At Punta Maria (7 in Fig. 1) south of Rio Grande, AUER (1959, p.40) described a profile that may record a fossil shore, today covered by a thin peat layer, which at one point (Auers's point 6) has a thin marine layer in the level of about $2.7 \mathrm{~m}$ above a level of unspecified character (probably mean sea level). The marine environment of the thin clay layer is not documented and may therefore be questioned. Nevertheless, a Holocene maximum level in the order of $2-3 \mathrm{~m}$ above the $\mathrm{HTL}$ is consistent with the findings at La Misión. 
At Cabo Viamonte (8 in Fig. 1), (AUER, 1980) has a locality which was said to record an interglacial sequence. We investigated this site in details and measured three profiles for paleomagnetism in 1987.

The coastal erosion has cut across hills and depressions, and provided a good geological section. Seen in its entirety, it is quite clear that the "interglacial dy" of Auer represents the initial phase of a Holocene lake sequence, and that the covering "till" represents reworked shore deposits in this little lake. In the central area, there is a continual sequence from initial lake dy to Holocene lake deposits. The lake seems to have had its shore about $1.0-0.7 \mathrm{~m}$ above HTL

This lake, once inside the corresponding shore, may give a sensitive registration of the sea changes via its effects on the ground water level. The Holocene sea level maximum in this area may hence be put at 1.0-0.7 m above HTL, or rather somewhat lower. It could definitely not have been higher, however.

In 1989, we levelled a sedimentary profile in the river bank in the shore plain north of Cabo Viamonte. The estuarine sequence records a double profile; an old interglacial estuarine bed ending in a black soil at $2.3 \mathrm{~m}$ above MSL, and a Holocene estuarine bed up to $2.5 \mathrm{~m}$ above MSL with a covering soil up to $2.85 \mathrm{~m}$ above MSL This agrees well with a maximum Holocene HTL of about $1.0-0.7 \mathrm{~m}$ above the present HTL

At San Pablo (said to reach some 2-3 m above mean sea level), AUER (1959, p.36) has a locality called "Pirinaica". Inside a coastal barrier (9 in Fig. 1), there is an overgrown lagoonal area which at its base contains a clay that is claimed to be of marine origin. Its elevation is about $1.5 \mathrm{~m}$ above mean sea level. The marine origin is not well documented and may be doubted. A tidal flat deposit at this level seems quite reasonable.

In 1989, we levelled two sections at San Pablo. A Holocene sea level maximum at +1.5 $\mathrm{m}$ was established (followed by 4 subsequent beach ridge generations, the second one of which corresponds to the same $+1.5 \mathrm{~m}$ level). An interglacial level at about $+11.0-7.5 \mathrm{~m}$ was also established.

\section{THE BEAGLE CHANNEL}

According to ANDERSSON (1907), deltas and shore marks along the Beagle Channel show a general tilt from about $+3.5 \mathrm{~m}$ in the eastern part to about $+10 \mathrm{~m}$ at Ushuaia. According to CALDENIUS (1932), this would represent an ice lake stage and not a marine stage, however.

According to PORTER et al. (1984) sea level reached a Holocene maximum of about +3.5 m. According to RABASSA et al. (1986), the Holocene sea level maximum reached +8.5 m or, maybe, even $+12 \mathrm{~m}$. Both these analyses base their conclusions solely on singular elevated beach data and do not 
attempt to give a general analysis including negative evidence (i.e., "sea level cannot have reached this level").

We have tried to undertake a general analysis of all sea level indications along the northern side of the Beagle Channel; i.e., both positive evidence ("the sea level must have reached this level") and negative evidence ("the sea level cannot have reached this level"). We believe that the absence of marine wave washing and erosion in the surface of seawards facing slopes of glacial deposits may provide firm evidence that sea level never reached above the corresponding level. We term this "negative evidence". The presence of marine deposits (beach or lagoonal), on the other hand, represents "positive evidence" of former sea levels. Studies confined to raised "positive evidence" (PORTER et al., 1984; RABASSA et al., 1986) may lead to the selection of exceptional data; i.e., seismotectonically uplifted sites.

We find that the available sea level data cannot be expressed in one generally valid sea level curve (as those of PORTER et al., 1984 and RABASSA et al., 1986) but must be analyzed individually because of the strong influence of local tectonic differentiation. It seems significant in this connection to call attention to the fact that the 1949 earthquake had significant seismotectonic effects in the eastern shores of Lago Fagnano (10 in Fig. 1) as reported by AUER (1959, p.118).

AUER $(1959,1974)$ described two localities with raised marine deposits. In a bog south of Ushuaia, he found a marine clay reaching up to $4.5 \mathrm{~m}$ above HTL with a sea level. At Punta Pinguinos (11 in Fig. 1), he found a peat layer at $4.5 \mathrm{~m}$ above $\mathrm{HTL}$ with a transgressional contact dated at $7,450 \pm 100 \mathrm{BP}$ to a "varved" clay of proposed marine origin reaching up to $5.4 \mathrm{~m}$ above HTL The marine origin has been questioned by RABASSA et al. (1986).

PORTER et al. (1984) used Auer's data from Punta Pinguinos and added a raised beach at $3.55 \mathrm{~m}$ above HTL at Peninsula Gusano (12 in Fig. 1) that was dated at about 4,600 BP, and a raised beach at $0.65 \mathrm{~m}$ above HTL at Punta Piedra Buena (13 in Fig. 1) that was dated at about 1,500 BP (with a higher beach of the marine limit at $3.5 \mathrm{~m}$ above $\mathrm{HTL})$.

RABASSA et al. (1986) added several new data of raised marine deposits from the Beagle Channel area. The new data primarily come from the Lapataia area (14 in Fig. 1), some $18 \mathrm{~km}$ west of Ushuaia. At the coast (Bahia Lapataia), there is a sequence of marine beds in elevation of 1.5-1.8 $\mathrm{m}$ above sea level (with unspecified character of the zero level). The basal part $(+1.65 \mathrm{~m}$ ) was dated at $8,240 \pm 60 \mathrm{BP}$ and the upper level at $5,800 \pm 65 \mathrm{BP}$. It is, of course, of great significance that sea level reached the $\pm 1.6 \mathrm{~m}$ level in this area as early as at about 8,250 BP. From the outlet area of Lago Roca, Rabassa et al. describe dated marine deposits from three localites: Rio Ovando at $+6.0 \mathrm{~m}$ (about $+7.2 \mathrm{~m}$ according to their section) dated at $4,425 \pm 55 \mathrm{BP}, \mathrm{El}$ Salmon at $+6.5 \mathrm{~m}$ (+8.2 $\mathrm{m}$ according to their section) dated at $3,860 \pm 75 \mathrm{BP}$, and Hosteria at +8.3 dated at 4,440 \pm 120 BP. From the shore of Lago Roca itself, they reported a marine bed at $+12 \mathrm{~m}$ dated at $5,920 \pm 90 \mathrm{BP}$.

According to my own observations within the same area, this is a highly tectonized area, 
however (cf. below).

From the Ushuaia Peninsula, RABASSA et al. (1986) cited two old dates of URIEN (1966): $\mathrm{a}+8.5 \mathrm{~m}$ beach at $5,400 \pm 270 \mathrm{BP}$ and $\mathrm{a}+5.0 \mathrm{~m}$ beach at $1,400 \pm 300 \mathrm{BP}$. From the Punta Pinguinos section of AUER $(1959,1974)$, they reported a new date of $7,095 \pm 75$ BP from wood within the "varved' clay which they, furthemore, classified as lacustrine and not marine as Auer did.

From Estancia Tunel (15 in Fig. 1), an archeological site east of Ushuaia, they reported "three levels of raised marine beaches" at $+3.2 \mathrm{~m},+4.5 \mathrm{~m}$ and $+6.4 \mathrm{~m}$ although no actual marine deposits were present. A midden on the middle "terrace" was dated at 4,870+90 BP.

From the Gable Island (16 in Fig. 1), they reported a non-marine Holocene sequence above a $+4.0 \mathrm{~m}$ level that includes a layer of lacustrine clay with "dropstones" which at its base contained

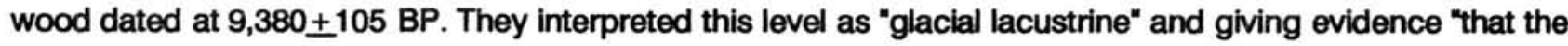
present Beagle Channel was still occupied by a glacial lake at 9,400 yr BP*

RABASSA et al. (1986) combined their data into a curve of relative sea level changes that peaked at $+8.5 \mathrm{~m}$ at about $5,500 \mathrm{BP}$.

We believe that the data presented by AUER $(1959,1970)$, URIEN (1966), PORTER et al. (1984) and RABASSA et al. (1986) can be - and must be - analyzed in a completely different way. This would result in a completely different picture where the individual data cannot be combined into one generally valid sea level curve, but where tectonic differentiation plays the dominant role for the present position of these uplifted marine deposits and beaches.

During the Swedish Expedition to Argentina in 1987, we studied the northern coasts of the Beagle Channel over an area of about $70 \mathrm{~km}$. We found - contrary to previous investigators - that the general rule was an absence of the effects (shore marks, deposits, wave washing) of a Holocene sea level above the present sea level by more than $0.5-1.0 \mathrm{~m}$. Marine deposits and shore features at higher elevations were found to represent tectonically uplifted sites.

In the area $5 \mathrm{~km}$ east of Rio Cambaceres (65 km east of Ushuaia), the shore morphology was studied in details in four separate profiles (17 in Fig. 1). In profile 1, there was a $60 \mathrm{~cm}$ difference between the present mean high-water mark and the present high high-water mark (HTL). A subrecent HTL was found $46 \mathrm{~cm}$ above the present HTL. The maximum Holocene shore mark lies $75 \mathrm{~cm}$ above the HTL. In profile 2, which crossed a tombolo, there is a $46 \mathrm{~cm}$ difference between the present $\mathrm{HTL}$ and the maximum Holocene level of the tombolo. In profile 3 , there is a $60 \mathrm{~cm}$ difference between the mean high-water mark and the HTL, and a $100 \mathrm{~cm}$ difference between the present HTL and the top of beach material against an unwashed slope. In profile 4, there is a $60 \mathrm{~cm}$ difference between the mean high-water mark and the HTL, a $47 \mathrm{~cm}$ difference between the present $\mathrm{HTL}$ and subrecent $\mathrm{HTL}$, and $87 \mathrm{~cm}$ difference between the present HTL and the top of Holocene beach material against a small cliff. This provides firm evidence of a Holocene maximum sea level only some $75-100 \mathrm{~cm}$ higher than the present one. We think this represents the general, 
not locally tectonized, Holocene sea level position at its maximum level.

At Harberton (18 in Fig. 1), the maximum sea level (HTL) is about or, at least, less than $1.0 \mathrm{~m}$ above the present HTL The same seems to be true for the entire coast in this part of the channel; i.e., over an area of about $15 \mathrm{~km}$ on each side of Estancia Harberton. At Gable Island (19 in Fig. 1), there are no traces of shore marks would easily have been cut.

At Rio Olivia (20 in Fig. 1), east of Ushuaia, there are large glaciofluvial accumulations. A +12 m glaciofluvial surface lacks all traces of washing and has obviously never been affected by wave washing; neither marine nor glaciolacustrine. It is covered by a midden. Below the glaciofluvial deposits there is a fossil shore and dune field close to the present shore. The shore is eroded in its eastern part where it is cut by the present shore, providing a good profile of the stratigraphy (Fig. 2). A fossil shore gravel occurs at about $1.0 \mathrm{~m}$ above the present shore gravel, signifying a maximum Holocene sea level not exceeding $+1.0 \mathrm{~m}$. Again, we believe that this represents a part coast has not suffered significant local tectonic movements during the Holocene.

In Ushuaia, there are no clear traces of higher sea levels. In the city, there is a terrace like plain, however, in the +2-3 $\mathrm{m}$ level. An excavation for a house foundation in the slope inside this "terrace" provides a good section of the stratigraphy. The upper surface at $+8-10 \mathrm{~m}$ (and also this "terrace" like) shows no sign of washing nor does the foot or the slope of the $+3 \mathrm{~m}$ " terrace", indicating that the waves did not reach these levels; i.e., +3-10 $\mathrm{m}$. Two till beds were exposed, none of which shows sign of washing. Therefore, neither the Holocene nor the late glacial sea (or glacial lakes) seems to have reached these levels. Many road cuts and other fresh cuts in the Ushuaia area show a total absence of effects from wave action.

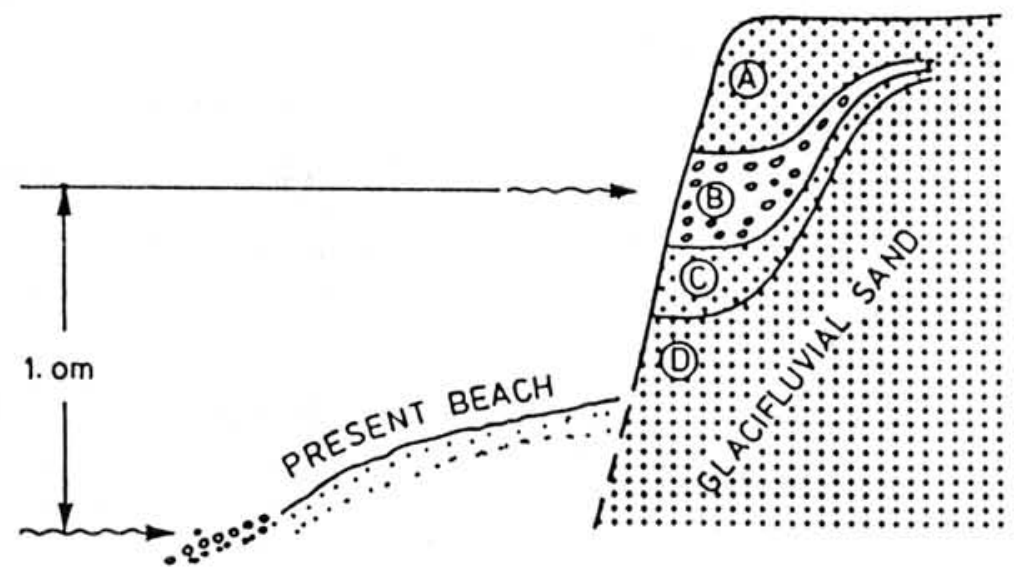

Figure 2 - The Holocene sea level maximum at Rio Olivia, east of Ushuaia. A fossil beach gravel (B) is located at an elevation of 1.0 $m$ above the corresponding deposits on the present beach. Below (C) and above (A) this beach gravel (B) there are onshore deposits equivalent to that of the present beach. The entire fossil beach is cut into glaciofluvial sand (D). 
At Ensenda (21 in Fig. 1), west of Ushuaia, there are no traces of Holocene sea levels higher than maximum $+1 \mathrm{~m}$ (or rather lower).

Even at the coast of Lapataia, there are no clear traces of Holocene sea levels higher than $2 \mathrm{~m}$ above HTL We studied the sections, described by RABASSA et al. (1986). In fact, there are two levels: an upper marine level (silt with shells dated at 7,260 $\pm 70 \mathrm{BP}$ in the top and $8,240 \pm 60 \mathrm{BP}$ in the base) at $+1 \cdot 5-1.0 \mathrm{~m}$, and a lower level (silt with shells dated at 5,800+65 BP) at $+0.5-1 \cdot 0 \mathrm{~m}$. The marine beds do not provide information about their relation to the corresponding sea levels. They seem, however, all to be shallow water deposits, not to say estuarine. They form two small plains at $+2 m$ and $+1 \mathrm{~m}$, respectively. Marine deposits at $+1.5 \mathrm{~m}$ at 8,250 BP (and even at 7,250 BP) are anomalously high both with respect to the corresponding level at La Misión (above) and international curves (MÖRNER, 1980), and give evidence of crustal uplift. Present erosion in a midden and overgrown shore deposits may signify a recent rise in sea or crustal subsidence.

\section{SEISMOTECTONICS}

To interprete the sea level data from Bahia Lapataia, it seems necessary to advocate 3 seismotectonic events that generated local co-seismic uplifts in the order of $2-3 \mathrm{~m}$ and with a recurrence interval of about 1,500 years between the $8,250,7,250$ and 5,800 BP levels.

Similarly, the Lago Roca dates seem to call for at least 2, probably more, seismotectonic uplifts, causing a $6.5 \mathrm{~m}$ uplift between the $+12 \mathrm{~m}$ level at 5,900 BP and the levels around $+7-8 \mathrm{~m}$ at around 4,450-3,850 BP and a $7.5 \mathrm{~m}$ uplift (or a sequence of smaller steps) after $3,850 \mathrm{BP}$.

The outlet area of Lago Roca gives an unnatural impression with a double outlet system and unstabilized erosional-equilibrium conditions. The western side of Lago Roca is crossed by a system of 5-6 young en echelon faults. The outlet is crossed by a young fault and (further to the west) a major trenchlike fault zone. Obviously, the area has suffered young tectonism. The sea level data indicate seismotectonics with co-seismic block movements where uplift seems to have dominated. These data are therefore considered to represent the exceptions (not the rule) and must accordingly not be used for the construction of regional sea level curves as done by RABASSA et al. (1986).

Raised beach data from the Ushuaia peninsula were used by RABASSA et al. (1986) for the construction of their Beagle Channel sea level curve. It is true that high sea levels occur in the island, but only on the northwestern side; for the rest maximum Holocene sea level is at or shortly above the present sea level. We investigated the coast around the entire island and established 7 levelled sections (Fig. 3). In Figure 3, we have combined our data into a composed profile all from Punta Pinguinos in the SW (1) to the easternmost point (8). The diagram gives clear and inquestionable evidence of seismotectonic uplift and 


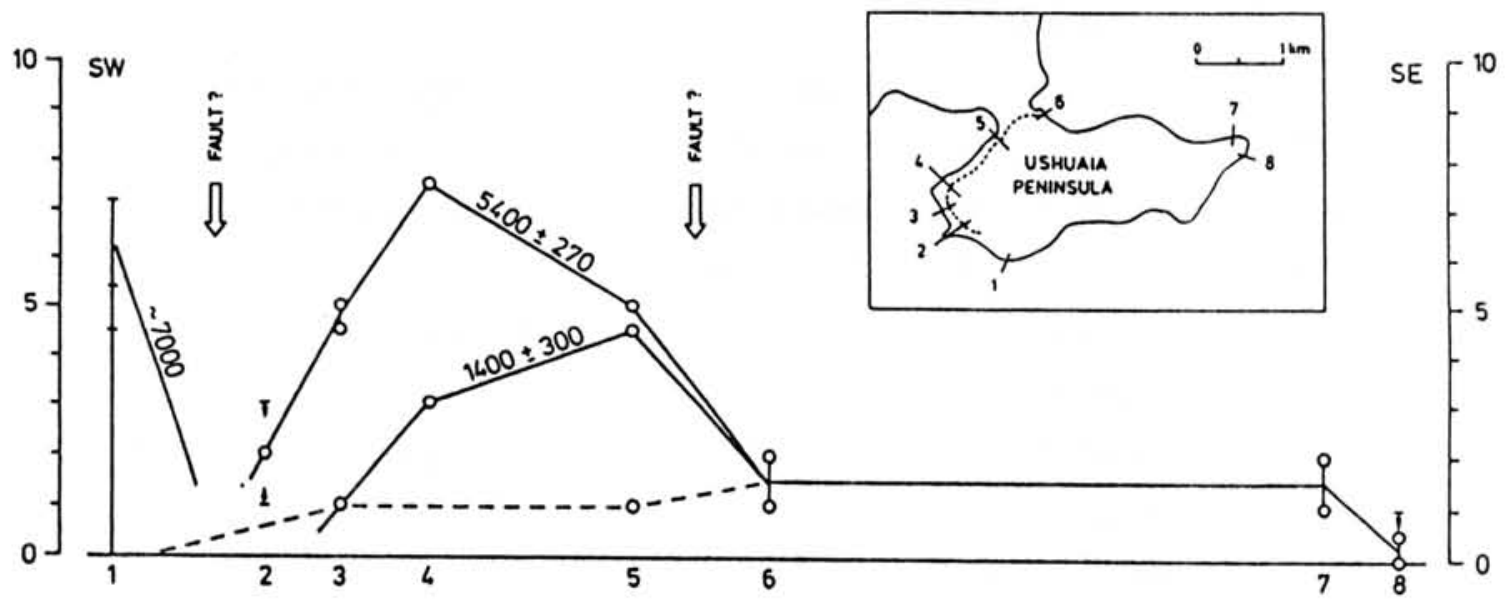

Figure 3 - Sea level data from the Ushuaia Peninsula. Inserted map show location of 8 sites investigated. The main diagram gives the corresponding sea level from point 1 (Punta Pinguinos) around the peninsula to point 8 on the eastern point. In the eastern part of the peninsula the Holocene sea level maximum is at about 0.5-1.5 m above present sea level. This agrees with the general characteristics in the Beagle Channel area. The western side of the peninsula, however, is strongly tectonized with uplifted and tilted shorelines (that may be bounded by faults). Obviously, the area has suffered repeated seismotectonic events with local co-seismic deformations of the crust. These uplifted and tilted shoreline data represent exceptions that must not be used in the reconstruction of the regional sea level changes.

tilting of separate blocks. At about 7,000 BP, the Punta Pinguinos area was strongly uplifted and tilted towards the north (if not bounded by a fault). This may have caused the change from landsurface conditions to a lake (or estuary) with final cover of gravelly deposits. Shortly after 5,400 BP, the NW-side was strongly uplifted and tilted towards the SE (with maximum uplift at point 4). At about 1,400 BP (judging from Urien's 1966 date), there was a third uplift and tilt of the NW-side (with maximum uplift at point 5). This tilting seems to be responsible for the present erosion (i.e., subsidence) at Punta Pinguinos. There seems to be a fault between points 5 and 6 , and possibly also between points 1 and 2 . In points 7 and 6 , the maximum level seems not to have exceeded $+0.5 \mathrm{~m}$.

Figure 3 expressively illustrates the danger, not to say serious mistake, in selecting singular high sea level data and ignore the general characteristics of the area.

We find that the general characteristics of the area is that the maximum Holocene sea level reached only slightly (0.5-1.0) above the present sea level, and that beaches and deposits at higher elevations represent local seismotectonic uplift.

Furthermore, it should be of great significance for the habitation and industrial utilization of the Ushuaia peninsula that is a highly seismotectonically active area that is bound to suffer future events, too. 


\section{GLACIAL ISOSTASY}

Tlerra del Fuego has been claimed to record a glacial isostatic differential uplift (ANDERSSON, 1907, and many subsequent authors including PORTER et al., 1984, and RABASSA et al., 1986). A mathematical modelling of "the effect of Patagonian ice sheet on relative sea level" has been attempted (CLARK \& BLOOM, 1979).

Our reinterpretation of the raised marine features in terms of local seismotectonic uplift, and our establishment of a general - regional eustatic - Holocene sea level rise to a maximum at or only shortly above the present position, indicate that the region cannot have undergone any significant glacial isostatic uplift and warping in Holocene time (cf., MÖRNER, 1987, 1989a). The sea level curve remaining after the subtractions of the data obviously representing seismotectonically uplifted sites exhibits a close similarity to the relative sea level curves calculated by CLARK \& BLOOM (1979, Figs. 2-3) for "no ice sheet" in Patagonia.

The late glacial shoreline in the Punta Arenas region, dipping from about $+7 \mathrm{~m}$ in the south to about $+3 \mathrm{~m}$ in the north and the shoreline along the northern side of Bahia Inutil,dipping from about $5.8 \mathrm{~m}$ in the west to about 4.2-5.0 $\mathrm{m}$ in the east (and still lower further eastwards in the bay) represent a gentle glacial isostatic warping of about 16,000 BP. This uplift had died out before the Holocene transgression reached the present level in mid-Holocene time. A similar gentle late glacial tilt may well be present in the Beagle Channel region. Taken together, this may signify an ice dome centered over the Islas Clarence - Peninsula Brecknock area. The glacial isostatic uplift amplitude is consistent with an ice thickness of not more than about $400 \mathrm{~m}$, however.

\section{REGIONAL EUSTASY}

A detailed and well founded regional eustatic curve for the Tierra del Fuego region cannot yet be defined; only a first approximation. We have seen that the sea level curves of PORTER et al. (1984) and RABASSA et al. (1986) both must be thoroughly revised. A Holocene sea level maximum at about the present sea level up to some $0.5-1.0 \mathrm{~m}$ or some 1-2 $\mathrm{m}$ above sea level has been documented as a general characteristics of the region. Prior to this optimum, sea level experienced a general rise all from about 9,000 BP judging from the dates in La Misión.

The marine clay and silt in La Misión with alternating amount of reducing/oxidizing conditions (black/grey colouring due to FeS changes) is a tidal flat deposit built up to HTL This gives a new background for the evaluation of the related sea level changes (MÖRNER, 1989a, 1989b, 1989c). In Figure 4, we have combined our 4-cores proflle with the cores of AUER (1959) and MARKGRAF (1980). An initial lake 

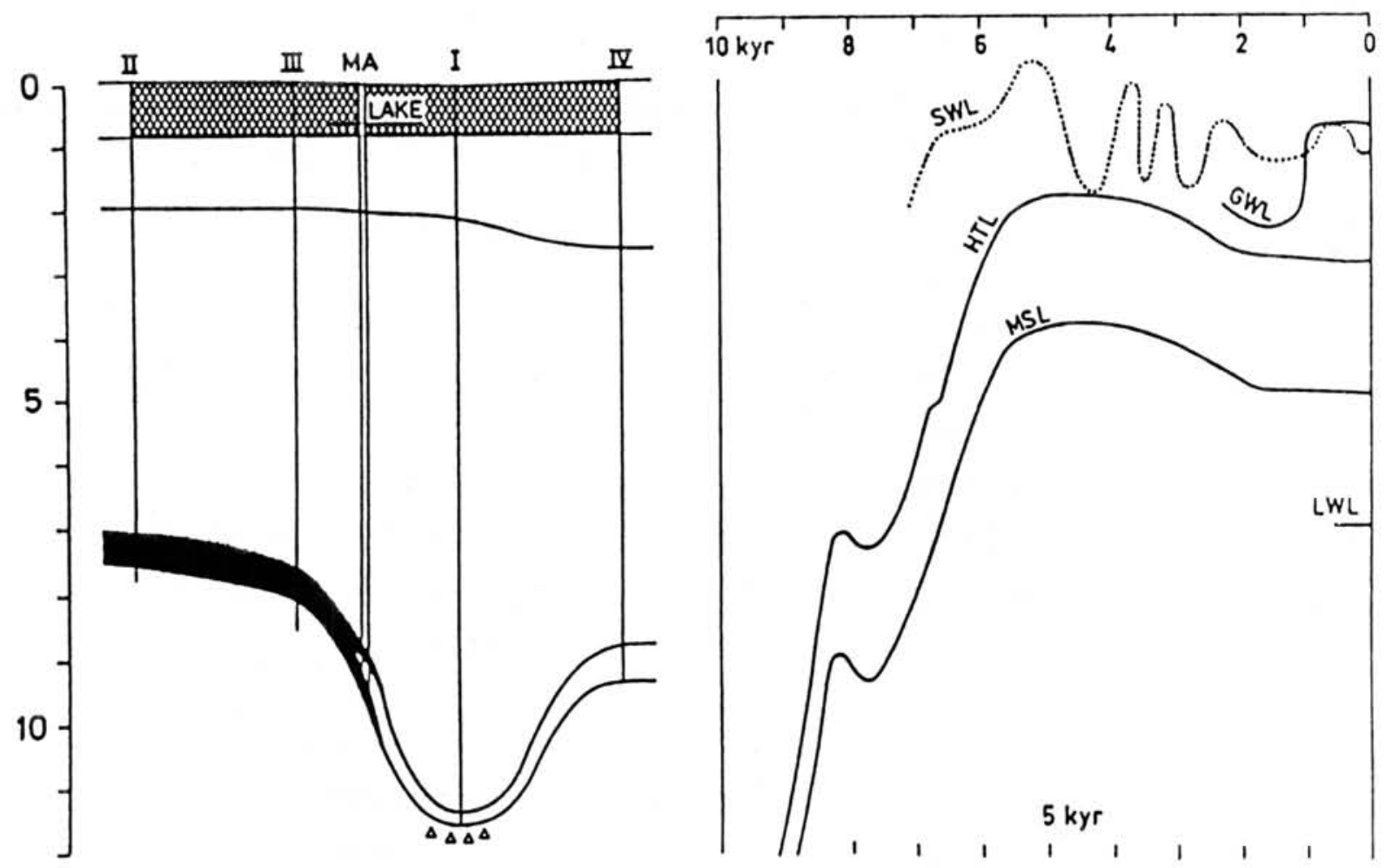

Figure 4 - The sedimetary core profiles at La Mision established by our four cores (1-M) with the inferred position of the cores by Auer (A) and Markgraf (M), recording an initial lake phase (about $9,000 \mathrm{BP}$ ), a transgresed peat surfaces (about 8,000 BP), a thick tidal flat bed, a primarilly lacustrine clay that is weathered, and a covering peat (of last centuries). The corresponding sea level changes are given to the right. The four curves record mean sea level (MWL), high tide level (HTL), storm wave level (SWL) and ground water level in the lake bog area (GWL). MSL and HTL refer to the sediment profile, whilst SWL refers to the beach ridge system and regression level in the profile and is quite approximative. This graph (MSL and HTL) can be taken as an approximate regional eustatic sea level graph for the Tierra del Fuego region.

phase with its level at about $5.7 \mathrm{~m}$ below HTL $(8.5$, down) was transgressed at about 9,000 BP. (It should be noted that the irregularities of the three radiocarbon dates given by MARKGRF, 1980, show a quite similar pattern to that obtained by MÖRNER, e.g., 1980, Fig. 6, in Sweden for the onset of a major sea level rise at about 9,000 BP; his PTM-1 peak). AUER (1959) found a second peaty layer in the level (here recalculated) of about $5.5 \mathrm{~m}$ below HTL that was dated at about 7,850 BP.. This may represent a short halt in the eustatic rise (It should be noted that the date agrees perfectly well with the onset of the PTM-2 transgression of MÖRNER, 1969, 1980, defined from data in Sweden). AUER (1959) also found a third peaty horizon in the (recalculated) level of about $2.2 \mathrm{~m}$ below HTL (5.1 $\mathrm{m}$ down). This may signify a second minor irregularity in the general sea level rise although this layer was not refound in the cores of Markgraf and Mörner. At a core depth of about $2 \mathrm{~m}$ (corresponding to a level of about $1.0 \mathrm{~m}$ above HTL), the sediment characteristics 
changed markedly in our core. This is also well established in the magnetic susceptibility of the sediments (Fig. 5). We interprete this as a paleoenvironmental change from tidal flat deposits to more pure lacustrine conditions. This seems to fit reasonably well with the diatomological changes established in Auer's core (AUER, 1959 and FRENGUEL, 1953). Occasionally, however, the sea must have reached even up to the level of $2.0 \mathrm{~m}$ above HTL In this level, however, it seems to be the effects of the storms and extra high waves rather than a real tidal flat level (Fig. 4). Because the sediments are strongly weathered all the way down to the level of $0.9 \mathrm{~m}$ above HTL ( $2.1 \mathrm{~m}$ down in the core), the ground water level must have been, at

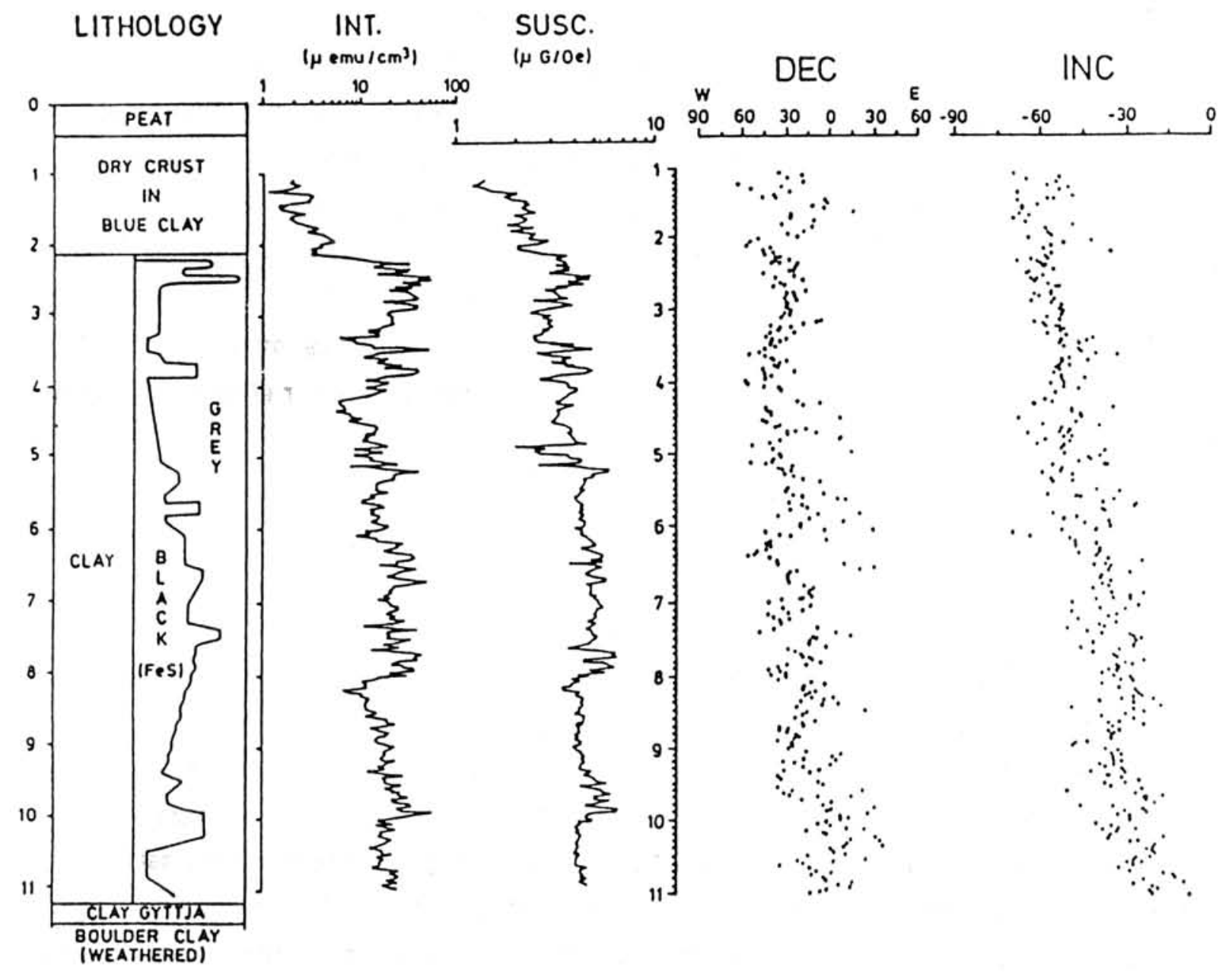

Figure 5 - Sedimentological changes was paleomagnetic records in the 1987 core. At a depth of $2.1 \mathrm{~m}$ there is a marked change in lithology that is well expressed in the intensity (Int) and susceptibility (Susc) records. This level seems to mark the end of direct tidal flat conditions. It also marks the boundary of postdepositional weathering before a late ground water rise (GWL) that gave rise to the present lake and peat over-growth. Declination (Dec) and inclination (Inc) are given after AF demagnetization in 200 Oe peak field. 
least, this low after the sea level maximum and before the present peat overgrowth. The peat overgrowth implies a late rise of the ground water level from $0.6 \mathrm{~m}$ above HTL to about $2.2 \mathrm{~m}$ above HTL (i.e., a rise of $1.6 \mathrm{~m}$ ). This must represent a significant paleoclimatic change from drier-warmer conditions to wetter-cooler conditions (cf., VON POST, 1931). A radiocarbon date from the middle of the peat gave an age of $270 \pm 120$ BP (MARKGRAF et al., 1989), indicating that this change took place only a few centuries ago (Fig. 4).

From this analyses, we may construct a new sea level curve for La Misión (Fig. 4). With minor local adjustments like a somewhat lower Holocene maximum in areas like Cabo Viamonte and the Beagle Channel, this curve may be taken as an approximate regional eustatic curve.

\section{GEOIDAL DIFFERENTIATION}

When two or more regional eustatic curves are compared, the effect of the geoidal deformation can be calculated (MÖRNER, 1981, 1983, 1984). The Tierra del Fuego curve (Fig. 4) lies above the regional eustatic curve of Brazil by a factor of about $0.55 \mathrm{~m} / 1,000$ years which seems to be more or less linear for the last 7,000 years. The difference between the Tierra del Fuego curve and the regional eustatic curve of NW Europe has an exponential shape with a $15 \mathrm{~m}$ difference at 9,000 BP, 8m at 8,000 BP and $2.5 \mathrm{~m}$ at 4,000 BP, the European curve lying below the Tierra del Fuego curve. This implies significant geoid changes within the Holocene. The data for the earlier period suggest even larger effects but of opposite sign.

\section{CONCLUSIONS}

Previous sea level curves for the Tierra del Fuego area have been found to be seriously affected by data from locally uplifted sites. Seismotectonic events with significant effects on the local crustal stability are inferred. The general rule of sea level changes is a rise from 9,000 BP up to about 4,000 BP to a level only slightly above the present; ranging from zero via $0.5-1.0 \mathrm{~m}$ up to $1-2 \mathrm{~m}$. An approximate regional eustatic curve is proposed. No effects of glacial isostasy are identified in the Holocene sea level data. Interregional deformations of the Holocene geoid level are recorded. A change from drier-warmer to wettercooler climatic conditions taken place a few centuries to half a millennia ago, is recorded in the data from La Misión. 


\section{REFERENCES}

ANDERSSON, J.G. (1907) Geological fragments from Tierra del Fuego. Bulletin of the Geological Institutions of the University of Uppsala, 8:169-183.

AUER, V. (1959) The Pleistocene of Fuego - Patagonia. Part III: shoreline displacements. Annales Academiae Scientiarum Fennicae, Ser.A, Sec.3, 60:1-247.

AUER, V. (1970) The Pleistocene of Fuego - Patagonia. Annales Academiae Scientiarum Fennicae, Ser.A, Sec.3, 100:1-194.

AUER, V. (1974) The isorhythmicity subsequent to the Fuego - Patagonian and Fennoscandian ocean level transgressions and regressions of the latest glaciation. Annales Academiae Scientiarum Fennicae, Ser.A, Sec.3, 115:1-88.

CALDENIUS, C. (1932) Las glaciaciones Cuaternarias en la Patagonia y Tierra del Fuego. Geogr.Ann., p.1164.

CAPPANNINI, D.A. (1954) Analysis microscópico de las muestras correspondentes a varios profiles de la turbera del rio de La Misión, Rio Grande, Tierra del Fuego. Annales Academiae Scientiarum Fennicae, Ser.A., Sec.3, 41:1-63.

CLARK, J.A. \& BLOOM, A.L (1979) The effect of the Patagonian ice sheet on relative sea levels along the Atlantic coast of South America: a numerical calculation. In: INTERNATIONAL SYMPOSIUM ON COASTAL EVOLUTION IN THE QUATERNARY. São Paulo, 1978. Proceedings. São Paulo, Brazilian National Working Group for the IGCP, cooperation with IG/USP, SBG. p.61-76.

FRENGUEШ, J. (1951) Analysis microscópico de las muestras de la turbera del rio de La Misión, Rio Grande, Tierra del Fuego. Annales Academiae Scientiarum Fennicae, Ser.A., Sec.3, 26:1-60.

FRENGUELL, J. (1953) Analysis microscópico de una segunda serie de muestras de la turbera del rio de La Misión, Rio Grande, Tierra del Fuego. Annales Academiae Scientiarum Fennicae, Ser.A., Sec.3, 34:1-52.

MARKGRAF, V. (1980) New data on the late - and postglacial vegetational history of La Misión, Tierra del 
Fuego, Argentina. In: INTERN. PALYNOL CONF. LUCKNOW, 4., India, 1976/77. Proceedings. India. v.3, p.68-74.

MARKGRAF, V.; BRANDBURY, J.P.; BROUWERS, E.M.; MÖRNER, N.A. (1989) Paleoenvironmental history of La Misión, Tierra del Fuego. Manuscript.

MÖRNER, N.A. (1969) THe late Quaternary history of the Kattegatt sea and the Swedish West Coast: deglaciation, shorelevel displacement, chronology, isostasy and eustasy. Sveriges Geologiska Undersökning, Ser.C., 140:1-487.

MÖRNER, N.A. (1980) Late Quaternary sea - level changes in northwestern Europe: a synthesis. Geologiska Föreningen i Stockholm Förhandlingar, 100:381-400.

MÖRNER, N.A. (1981) Eustasy, paleogeodesy and glacial volume changes. In: IUGG Symp. 2, IAHS Publ., Proceedings, 131:277-280.

MÖRNER, N.A. (1983) Sea levels. In: GARDNER, R.AM. \& SCOGING, H. (eds.) Mega-geomorphology. Oxford, University Press. p.73-91.

MÖRNER, N.A. (1984) Differential Holocene sea level changes over the globe: evidence for glacial eustasy, geoidal eustasy and crustal movements. Litoralia, 1:83-86.

MÖRNER, N.A. (1987) Seal level changes and tectonics in Tierra del Fuego. Bulletin INQUA Neotectonics Comm. (10):31.

MÖRNER, N.A. (1989a) Changes in the coastal sedimentary environments. The South American case and implications on Global Changes. In: INTERNATIONAL SYMPOSIUM ON GLOBAL CHANGES IN SOUTH AMERICA DURING THE QUATERNARY, São Paulo, 1989. Special Publication, 1: Program, Abstracts and General Informations. São Paulo, ABEQUA/INQUA. p.216-220.

MÖRNER, N.A. (1989b) Holocene sea level changes in the Tierra del Fuego region. Bulletin INQUA Neotectonics Comm., (12):85-87.

MÖRNER, N.A. (1989c) New data from La Misión, Tierra del Fuego, Argentina. Intern. Proj. Paleolimnology Late Cenozoic Climate, (5):9-11. 
PORTER, S.C.; STUIVER, M.; HEUSSER, C.J. (1984) Holocene sea-level changes along the Strait of Magellan and Beagle Channel, southernmost South America. Quaternary Research, 22:59-67.

RABASSA, J.; HEUSSER, C.; STUCKENRATH, R. (1986) New data on Holocene sea transgression in the Beagle Channel, Tierra del Fuego, Argentina. Quatemary of South America and Antarctic Peninsula, (4):291-309.

URIEN, C.M. (1966) Edad de algunas playas elevadas en la Peninsula de Ushuaia y su relacion con el ascenso costero, pos-glaciario. In: III J.Geol. Argentinas. Proceedings, 2:35-41.

VON POST, L. (1931) Eldslandets postglacial Klimathistoria. Geologiska Föreningen I Stockholm Forhandlingar, 53:373-374.

VON POST, L (1946) The prospect for pollen analysis in the study of Earth's climatic history. The New Phytologist, 45(2):193-217. 